\title{
Combating the Resource Curse: An Alternative Solution to Managing Mineral Wealth
}

\author{
Erika Weinthal and Pauline Jones Luong
}

\begin{abstract}
Countless studies document the correlation between abundant mineral resources and a series of negative economic and political outcomes, including poor economic performance, unbalanced growth, weakly institutionalized states, and authoritarian regimes across the developing world. The disappointing experience of mineral-rich countries has generated a large body of scholarship aimed at explaining this empirical correlation and a list of prescriptions for combating the resource curse. The most popular solutions emphasize macroeconomic policies, economic diversification, natural resource funds, transparency and accountability, and direct distribution to the general population. The success of these solutions has been limited because they either presuppose strong state institutions, which are widely absent in the developing world, or assume state ownership over mineral wealth and thus the need for external actors to constrain the state. At the same time, domestic private ownership is rarely proposed and often maligned. Yet, in some countries, it would serve as a more viable way to avoid the resource curse by fostering institutions that more effectively constrain state leaders, encouraging them to invest in institution building, and enabling them to respond more successfully to commodity booms and busts.
\end{abstract}

T he race to find new sources of petroleum has been ongoing since commercially viable oil was discovered in Titusville, Pennsylvania in 1859. Almost a century and a half later, the discovery of new oil wealth in several parts of the world, including Azerbaijan, Kazakhstan, East Timor, Chad, and Sudan has muffled increasingly popular cries that world oil production would ultimately peak by the middle of this decade. ${ }^{1}$

For most industrial countries heavily dependent upon fossil fuels for economic growth, these new petroleum sources were a welcome blessing that could delay an impending global energy shortage. Europe's reliance upon imported oil and gas is expected to increase dramatically

Erika Weinthal is associate professor of environmental policy in the Nicholas School of the Environment and Earth Sciences at Duke University (weinthal@duke.edu). Pauline Jones Luong is associate professor in the Department of Political Science at Brown University (pauline_luong@ brown.edu). This article is part of a long-term joint project; the authors are rotating authorship on the articles they publish, sharing equal responsibility for the content and analysis herein. They gratefully acknowledge comments and suggestions from Richard Auty, Anna Grzymala-Busse, Victoria Murillo, Richard Snyder, the Colloquium on Comparative Research at Brown University, and three anonymous reviewers. over the next few decades, especially as oil production in the North Sea declines from approximately seven million barrels per day to less than four million barrels per day by $2020 .^{2}$ Similarly, the United States has become increasingly dependent upon foreign petroleum supplies since 1998 when petroleum imports surpassed the 50 percent barrier for the first time. ${ }^{3}$ These new petroleum discoveries are even more vital for meeting the rising energy demand in the world's fastest growing economies of developing Asia including China and India. ${ }^{4}$

For the countries where these discoveries were made, however, new concerns arose over whether they could avoid the curse associated with mineral wealth. Countless studies document the correlation between abundant mineral resources (for example, oil, gas, diamonds, copper, and gold) and a series of negative economic and political outcomes, including poor economic performance and authoritarian regimes, across the developing world. ${ }^{5}$ There are also numerous empirical examples of countries that have squandered their mineral wealth and actually made their citizens worse off. Nigeria (the world's seventh largest oil producer) provides a notorious one. Its government has accrued $\$ 350$ billion in oil revenues since independence, and yet its economy has shrunk; in purchasing power parity (PPP) terms, Nigeria's per capita GDP was $\$ 1,113$ in 1970 but only $\$ 1,084$ in 2000 , and during this same period, its poverty rate, "measured as the share of the population subsisting on less than US $\$ 1$ per day increased from close to 36 percent to just under 70 percent." ${ }^{6}$ Thus, 
despite its vast oil wealth, Nigeria is among the 15 poorest nations in the world.

The disappointing experience of mineral-rich countries has generated a large body of scholarship aimed at explaining this empirical correlation and a list of prescriptions for combating the resource curse. The most popular solutions emphasize macroeconomic policies, economic diversification, natural resource funds, transparency and accountability, and direct distribution as mechanisms for managing mineral wealth wisely. While many mineral-rich countries in the developing world have implemented one or more of these solutions, their success has been limited to only a few exceptional cases (for example, Botswana, Chile, and Malaysia). We contend that this is because these solutions either presuppose strong state institutions, which are widely absent in the developing world, or assume state ownership over mineral wealth and thus the need for external actors to constrain the state.

Despite the emerging consensus that robust political institutions are the determining factor in successful efforts to disrupt the link between mineral wealth and the aforementioned negative outcomes, we know little about how to build such institutions. We suggest one possible waydomestic private ownership. Domestic private ownership is rarely discussed in the literature and, when discussed, it often is maligned. Our research indicates, however, that it would foster institutions that more effectively constrain state leaders, encourage them to invest in institution building, and enable them to respond more successfully to commodity booms and busts.

\section{The Paradox of Mineral Wealth}

The central paradox that has inspired innumerable studies of mineral-rich countries in the developing world is that, since the 1970s, they have consistently underperformed their mineral-poor counterparts on a variety of economic and political indicators, including economic performance, good governance, income equality, and democracy.

It has been well established that-controlling for income- the more intense a country's reliance on mineral exports (measured as a percentage of GDP) during this time period, the more slowly its economy grew. ${ }^{7}$ From 1960 to 1990 , GDP per capita in mineral-rich countries increased 1.7 percent compared to $2.5-3.5$ percent in mineral-poor countries; similarly, from 1970-1993, mineral-rich countries grew by only 0.8 percent PCGDP compared to 2.1-3.7 percent in mineral-poor countries. ${ }^{8}$ A prominent illustration of this surprising result are the "tigers" in mineral-poor East Asia (Hong Kong, Korea, Singapore and Taiwan), whose economies maintained phenomenal growth rates from the early 1960 s to the 1990 s while the economies of mineral-rich Latin America stagnated or declined. ${ }^{9}$ Also during this period (roughly 19651998), members of the Organization of Petroleum
Exporting Countries (OPEC) experienced nearly universally low or negative annual growth rates. ${ }^{10}$

Mineral exporters were also more likely to incur greater debt, even as world prices soared, and thus forced to commit a significant percentage of their shrinking GDP to debt servicing. ${ }^{11}$ The World Bank classifies 12 of the world's most mineral-dependent countries and six of the world's most oil-dependent countries as "highly indebted poor countries." 12 Six out of the top 10 most indebted countries in Africa are major fuel exporters. ${ }^{13}$ Outside Africa, similar patterns emerge; although Ecuador is one of the smallest countries in South America, in 2002 it ranked seventh in the region for external indebtedness-just below Brazil, Argentina, and Venezuela — and had the highest debt per capita. ${ }^{14}$

Related to these economic problems is the consistent finding that mineral wealth is strongly correlated with poor governance and high levels of corruption-all the more so if the primary commodity is oil. ${ }^{15}$ Mineral exporters in the developing world find themselves ranked at the bottom of the list among countries included in both the World Bank Governance Research Indicators ${ }^{16}$ and the Transparency International's Corruption Perception Index (CPI). ${ }^{17}$

Mineral-exporting states also fare much worse when it comes to standards of living and the condition of the poor. Citizens living in such countries are subjected to high levels of poverty, child mortality, and income inequality. ${ }^{18}$

Finally, mineral-dependent countries tend to have authoritarian regimes. Several studies exploring this relationship have found that mineral wealth not only impedes democratic transitions but also prevents the consolidation of democracies, ${ }^{19}$ and conversely, promotes the consolidation of authoritarian regimes..$^{20}$ Oil wealth in particular has been identified as inhibiting democratization, especially in oil-poor and low-income countries-thus indicating that even a little "oil does hurt democracy." 21 Of the 20 major oil exporters in 2000, only Mexico and Venezuela-both of which have previously experienced long periods of dictatorship_could be classified as democracies.

That mineral-abundant countries in the developing world are more prone to poor economic performance, unbalanced growth, corruption, income inequality, and authoritarian regimes is certainly alarming, especially given the initial optimism about their future prospects. In the 1950s and 1960s many development economists argued that these countries would grow much faster than their resource-poor counterparts precisely because their mineral wealth would provide them with the necessary capital to industrialize and diversify their exports. ${ }^{22}$ Economic growth, in turn, was widely believed to promote the degree of social change and income equality necessary for democratization. ${ }^{23}$ What is even more striking, then, is that by 
the 1990s a scholarly consensus emerged that these countries' vast wealth is the root cause of their severe political and economic problems - often referred to as the "resource curse."

These scholars emphasize two main aspects of the resource curse: first, the economic consequences that rapid booms and the volatility of commodity markets have for sustained growth; and second, the negative impact that reliance on external rents has on governance, state capacity, and democracy, which is exacerbated by boom and bust cycles. We review these briefly below.

\section{Windfalls and economic growth}

The most prevalent cause attributed to poor rates of economic growth in mineral-rich countries is Dutch Disease- a term originally coined to refer to the shortlived problems that the Netherlands faced when it discovered huge gas reserves off its northern coast in 1959. Yet, the direct effects of export booms - whether due to a rapid rise in exports or commodity prices-is a common source of economic stagnation across mineral-rich states. Simply put, these windfalls lead to an appreciation of the real exchange rate (that is, the rate of exchange between currencies adjusted for inflation) by shifting production inputs (capital and labor) to the booming mineral sector and non-tradable sector (that is, retail trade, services, and construction), thereby reducing the competitiveness of the non-booming export sectors (for example, agriculture and manufacturing) and hence precipitating their collapse. The shift into the non-tradable sector accelerates domestic inflation, which is responsible for the rise in the real exchange rate.

These short-term macro-adjustment problems result in long-term effects on growth by reducing the country's economic diversity and increasing its reliance on exports from its natural resource sector. Equatorial Guinea-one of Africa's newest oil producers-is illustrative of how fast Dutch Disease effects can transform the domestic economy: cocoa and coffee have declined from approximately 60 percent of GDP in 1991 to less than 9 percent of GDP in $2001 .^{24}$

The decline of the manufacturing sector also retards economic growth by decreasing both the demand for and supply of skilled labor, which in turn, affects the level of income inequality and educational opportunities. ${ }^{25} \mathrm{~A}$ number of recent studies have found, for example, that school enrollment at all levels and public expenditures on education relative to national income are inversely related to natural resource abundance. ${ }^{26}$

The phenomenon of Dutch Disease, however, is not the only mechanism whereby economic growth is negatively affected by windfalls. Perhaps equally important are the incentives that windfalls create for unproductive investments, rent-seeking, and corruption.
First, the export boom exerts pressure on governments to share increased revenues with the public, often by investing in unproductive public work projects that are motivated by politics rather than profit (that is, "white elephants") or subsidizing food, fuel, failing industries and even government jobs. ${ }^{27}$ There is no shortage of prominent examples, such as the Ajaokuta steel mill that Nigeria built in the 1970s to appease the Yoruba region, which "has absorbed over US\$3 billion," 28 and yet, "has still not produced a commercial ton of steel." ${ }^{29}$ In addition to squandering the proceeds from their most precious commodities on failed investment programs, countries also suffer from spiraling inflation, the collapse of private savings and investment, and economic stagnation. ${ }^{30}$

Second, many argue that because windfall rents are concentrated and easily obtained, they exert pressure to engage in rent-seeking and corruption-both of which harm economic growth. ${ }^{31}$ Windfalls can shift the focus to competition over rents, leading to a "feeding frenzy" 32 and thereby distract both individuals and governments from longterm developmental goals. ${ }^{33}$ For example, in the late 1960s and early 1970s Indonesia's state oil company, Pertamina, accrued large windfalls that generated rent-seeking opportunities for actors closely tied to the state; these mineral rents became a source of patronage for the Indonesian military. ${ }^{34}$ The long-term effects on Indonesia's economy are evident in the lack of foreign investment in new energy projects over the last decade and its unique distinction of becoming OPEC's first member to import oil in 2004. ${ }^{35}$

\section{Volatility and economic growth}

Another chief concern is the effect that the extreme volatility of commodities, also known as "boom and bust" cycles, can have on economic growth. Although market volatility is a problem for all exporters of primary commodities, it especially plagues oil exporters because the economic importance of oil makes this particular commodity both a valuable and an attractive political weapon.

The economic impact includes, first and foremost, unpredictable revenue streams because widely fluctuating export revenues lead to fluctuating levels in overall government revenues. ${ }^{36}$ These "frequent upward or downward adjustments of fiscal expenditures are costly" because they simultaneously discourage private investment and wreak havoc on the government's budget, thereby impeding its ability to sustain investment and public goods provision. ${ }^{37}$ Moreover, once expenditures become entrenched, it is harder for governments to make budget cuts; rather than reversing their spending patterns during busts, they often opt to borrow, and hence, incur huge debt burdens. ${ }^{38}$

Excessive borrowing also occurs during booms. Many countries have followed the ill-advised strategy of "borrow [ing] on the strength of their booms." ${ }^{39}$ For example, although it experienced "only a small oil windfall in 
1979-81," Mexico "borrowed abroad against future oil earnings to boost expenditures by a further 1.8 percent of non-oil GDP." 40 In fact, oil exporters "built up more debt during the 1970s" - that is, as oil revenues were rising the fastest. ${ }^{41}$

\section{Political consequences of reliance on external rents}

The main political consequences of relying on external rents ${ }^{42}$ are weakly institutionalized states and skewed statesocietal relations. Relying on an external source of revenue fosters weakly institutionalized states because the ease of financing state expenditures provides no incentives for government officials to build strong institutions. More specifically, countries rich in minerals, particularly petroleum, fail to develop a robust central bureaucracy because their ability to rely on an external revenue source engenders rigid and myopic decision making. ${ }^{43}$ This includes, most importantly, the failure to build a viable tax regime because rulers do not feel compelled to extract revenue from domestic sources to fill their coffers. ${ }^{44}$

In short, mineral-rich states inevitably become rentier states. Rentier states seek to exert social and political control over their populations by creating and maintaining economic dependencies through their sole authority to allocate and redistribute income obtained from natural resource rents. ${ }^{45}$ This has three critical implications for state-societal relations.

First, the freedom to rely on external rather than internal sources of income both enfeebles the state and impairs the development of societal opposition because it reduces both the need for leaders to be accountable to the public and popular demands for representation. ${ }^{46}$ Indeed, the lack of a viable tax regime has been consistently identified with not only impeding broad economic growth but also undermining state capacity and democratization. ${ }^{47}$

Second, rentier states bolster their autonomy from societal forces by exploiting their fiscal independence to engage in discretionary spending. Large sums of money are spent on sustaining patronage networks and/or providing huge subsidies to the population to garner social and political support, rather than on developing institutionalized mechanisms of responsiveness. ${ }^{48}$ The Kuwaiti government, for example, employed 75 percent of the workforce in 1975, but most were "underqualified and underutilized." 49 In short, these states are characterized by the "progressive substitution of public spending for statecraft." 50

Third, rentier states are subject to state capture and high levels of corruption. While the majority of the population is effectively disenfranchised, those who run the natural resource sector are able to exert disproportionate influence over government policies. There are primarily two reasons for this. First, the highly concentrated nature of the mineral sector enables the small number of firms that occupy it to form a united front to pressure the state.
Second, the sheer economic impact of the mineral sector fosters a tendency for the state to conflate this sector's interest with its own. ${ }^{51}$ The Gulf States, where the oil sector and the ruling families are nearly indistinguishable, represent the most extreme illustration. ${ }^{52}$ As a result, both sides have a vested interest in nontransparent transactions, thereby ensuring state autonomy vis-à-vis the broader population and enabling those with access to mineral rents (first and foremost, government officials) to enrich themselves at society's expense. ${ }^{53}$

The cumulative impact of external rent reliance, therefore, is not just weakly institutionalized states and skewed state-societal relations but also corrupt, authoritarian regimes. With unfettered access to huge rents, incumbents have such a disproportionate advantage over their opponents so that they can remain in office almost indefinitely. ${ }^{54}$ These regimes also sustain themselves by simultaneously creating a strong deterrent to popular mobilization-either because they successfully preempt social discontent with populist policies or because they possess effective internal security forces. ${ }^{55}$ The result is that only very few developing countries, such as the Republic of Congo and Venezuela, have been able to channel their oil wealth into creating the socioeconomic and political conditions conducive to democratic transition. ${ }^{56}$

Boom and bust cycles also play a role by aggravating the effects of external rents reliance. Booms exacerbate both state spending and rent-seeking behavior, thus reinforcing the dynamic of weakly institutionalized states and corrupt, authoritarian regimes. ${ }^{57}$ They also further enfeeble the state by actually creating a disincentive for state leaders to build strong institutions that might interfere with their ability to allocate rents to supporters. ${ }^{58}$ Weakly institutionalized states, in turn, are unable to respond to busts, either because their bureaucracies are too centralized and bloated to adjust, sectoral interests have captured the policy-making process, or some combination. ${ }^{59}$

\section{Proposed Solutions and their Limitations}

Because these scholarly accounts share the assumption that the revenue from mineral exports necessarily accrues directly to the state, the solutions they propose focus on ways to make the state a better "manager" of these proceeds. According to this view, the likelihood for the newest group of energy producers in the developing world (for example, Azerbaijan, Kazakhstan, Chad, Sudan, and East Timor) to avoid the above-mentioned negative economic and political outcomes associated with mineral wealth depends on whether their respective governments can utilize anticipated windfalls more effectively. Thus, the most common solutions proposed to help these states achieve this include (1) sound fiscal and monetary policies; (2) economic 
diversification; (3) natural resource funds; (4) transparency, accountability and pubic involvement; and (5) direct distribution to the population.

These solutions, however, are inherently limited by their emphasis on the state. In sum, they amount to either asking a weakly institutionalized state to employ capacities that it has not yet developed or relying on non-state actors (who often have little willingness or ability to do so) to monitor and constrain the state's behavior. States that are unable to prevent their own bureaucrats from rent-seeking, for example, are expected to implement policies that limit discretionary government spending. Moreover, many of the proposed revenue management policies depend on the ability of international financial institutions (IFIs) and nongovernmental organizations (NGOs) to exert sufficient pressure on state leaders.

This is particularly ironic given the broad consensus that weak institutions are perhaps the greatest impediment to escaping the resource curse. Despite this consensus, none of the aforementioned solutions are intended to rectify institutional weakness, but rather, to either simply ignore or circumvent it.

\section{Fiscal and monetary policy}

From the moment that the windfalls begin, the negative economic effects associated with Dutch Disease are imminent. ${ }^{60}$ As a first step to counter the appreciation of the real exchange rate, resource-rich states are urged to accumulate income-producing foreign assets in order to sterilize the local economy from the inflow generated by the mineral sector. ${ }^{61}$ The accumulation of budget surpluses and avoidance of large-scale foreign debt enables mineralrich countries to smooth out expenditures during boom periods and prevent borrowing during cycles of busts. Combined, these policies help to insulate the domestic economy from the volatility of commodity revenues and generate budget stability.

Botswana is a prominent example of just how successfully countries that implement sound macroeconomic policies and spend their windfalls wisely can combat the Dutch Disease. ${ }^{62}$ It has managed its exchange rate policy through the accumulation of foreign reserves and has run budget surpluses that were set aside for stability spending during periods of busts. Owing to its commitment to fiscal discipline, Botswana has shunned wasteful spending during boom periods and borrowing during busts. These policies have contributed to Botswana's rapidly growing GDP, which has enabled it to move from the 25 th poorest country in 1966 to an upper-middle income country within 30 years. ${ }^{63}$

So, why have so few countries followed Botswana's example? The predominant explanation is that an insulated and autonomous technocracy committed to long-term developmental goals is necessary for pushing through macro- economic policies that may be socially and politically unpopular. ${ }^{64}$ Yet, this overlooks the institutional capacity that carrying out and sustaining such polices requires-in particular, institutionalized mechanisms for accountability and transparency that can curb rent-seeking and corruption. More importantly, the sole reliance upon an autonomous technocracy overlooks the need for strong budgetary institutions and procedures that can constrain legislatures and ministries from expanding the budget and promoting "pet projects." ${ }^{65}$ Botswana was able to maintain a firm budget and prevent overspending because of a legislative procedure requiring parliamentary approval for any new public project after its National Development Plan was passed, thus preventing the executive branch from altering the budget. ${ }^{66}$

\section{Economic diversification}

To prevent the booming export sector and the non-traded goods sector (that is, retail trade, services, and construction) from crowding out the non-booming export sectors, mineral-rich countries have long been advised to invest windfalls in economic diversification. ${ }^{67}$ Thus, they will be able to shield their economies from shocks caused by market volatility. Economic diversification is also directly linked to sound fiscal and monetary policies - that is, when the local currency is not allowed to appreciate, the chance of decline in the non-booming sectors is reduced.

This is one of the rare areas in which policy prescriptions have been widely followed. With the endorsement of developmental economists and international organizations, such as the United Nations Conference on Trade and Development, the United Nations Economic Commission, and the World Bank, from the 1960s until the early 1980s most mineral-rich states made considerable investments in promoting other economic sectors. ${ }^{68}$

Efforts to mitigate the effects of Dutch Disease by transferring rents from the mineral sector to the non-booming export sectors, however, have actually had a decisively adverse economic effect. ${ }^{69}$ State-led investment in that historical context has led not only to inefficient investment but also to the perpetuation of import substitution industrialization and protectionism - both of which have independently contributed to stagnant growth rates. ${ }^{70}$ Moreover, few countries have actually managed to diversify their economies. ${ }^{71}$ Tunisia is the only mineral economy in 1970 that was no longer ranked as a mineral economy in $1991 .^{72}$ Thus, ironically, "the growth collapses of the late 1970s and the early 1980s resulted in the backfiring of the resource abundant countries' efforts to reduce their commodity dependence." 73

These policies have failed to decrease dependence on natural resource exports for the same reason that the majority of mineral-rich states have not implemented sound fiscal and monetary policies. Because these countries lack 
strong state institutions and a transparent decisionmaking process, they are prone to making poor investment decisions - that is, decisions that are based on either shaky economic ground or political priorities, and hence, do not offer high domestic rates of return. Thus, even for an outlier such as Indonesia, which has been widely touted for its ability to sustain a viable agricultural sector since the $1970 \mathrm{~s},{ }^{74}$ the lack of institutionalized mechanisms for accountability, transparency, and oversight has allowed rentseeking and corruption to flourish.

\section{Natural resource funds}

Natural Resource Funds (NRFs) consist of stabilization or savings funds and often combine both. Stabilization funds aim to reduce the impact of commodity price volatility on the economy and, in turn, improve budget predictability by stabilizing spending patterns. ${ }^{75}$ They reduce overspending when prices are high and borrowing when prices fall because when commodity prices are high, excess revenue is placed in the stabilization fund, but when prices are low, revenue is transferred out to make up for budgetary shortfalls. Savings funds, in contrast, are intended to ensure that a share of the wealth will exist for future generations, even after the natural resources are depleted. ${ }^{76}$

NRFs are found in both developed and developing countries. Examples include Venezuela's Stabilization Investment Fund, the State Petroleum Fund in Norway, Iran's Foreign Currency Reserve Account, and the Oman General Reserve Fund. However, their institutional structures and success rates vary dramatically. The Alaska Permanent Fund is characterized by high levels of public involvement in the decision-making process concerning the establishment and evolution of the fund. ${ }^{77}$ Public debate has influenced how the windfalls are spent and led to the creation of a dividend program in which each citizen of Alaska is entitled to a share of the wealth generated from oil sales. In contrast, the Kuwait Reserve Fund for Future Generations is considered extremely nontransparent since information about its holdings and expenditures is neither available to the public nor to the legislature.

The popularity of NRFs continues to grow. Several new energy producers-Azerbaijan, Kazakhstan, and Chadhave also adopted NRFs. Most recently, the World Bank and the International Monetary Fund (IMF) have proposed a Petroleum Fund model to East Timor to assist it with managing its anticipated petroleum revenues from its newly discovered offshore reserves. Yet, their applicability to developing countries is limited precisely because many lack the institutions to support NRFs.

In order for NRFs to work as designed, states must already possess strong state institutions - that is, institutions that emphasize oversight, transparency, and accountability such as a professional bureaucracy that abides by clear fiscal accounting standards and an independent judi- ciary that can prevent the executive from arbitrarily changing the rules. It is no coincidence that the most enduring NRFs are located in countries such as Norway, the United States, and Canada - all of which have well-developed fiscal, regulatory, and supervisory institutions and also happen to be mature democracies. ${ }^{78}$

The empirical evidence to date also indicates that NRFs have been largely ineffective in stamping out corruption and improving transparency in countries with strong chief executives that possess sole authority over petroleum contracts and complete discretion over the operation of the NRF. ${ }^{79}$ Venezuela's fund exemplifies the risks involved in proposing an NRF for a country-even if it is a democracy - in the absence of stringent checks on and balances against executive authority. As a result, the Venezuelan government has periodically raided the fund when strapped for cash, and frequently altered the fund's operating rules to expand presidential discretion. The weakness of Venezuela's fund does not bode well for the newly created NRFs in Azerbaijan and Kazakhstan-countries that both have strong presidencies. Already in its short history, former President Haider Aliev was personally able to channel resources from the NRF to finance refugee resettlement programs ${ }^{80}$ and the state oil company's (SOCAR) participation in the Baku-Ceyhan oil pipeline. ${ }^{81}$ Thus, where the institutional capacities necessary to support and restrict access to NRFs are absent, they can actually be counterproductive; rather than sterilizing the budget and preventing corruption, these funds can inadvertently reinforce the concentration of power and authoritarian tendencies in mineral-rich countries.

\section{Transparency, accountability, and public involvement}

Over the last few years, international nongovernmental organizations (INGOs) and IFIs have combined forces to promote transparency, accountability, and public involvement in the management of petroleum revenues in order to address the political consequences of reliance on external rents.

The targets of INGO activity include foreign extractive firms, IFIs, Western governments, and domestic governments. ${ }^{82}$ First, they have pressed IFIs such as the World Bank and IMF to use their leverage to encourage countries to provide the public with accurate information about revenues received and spent. Second, they have pushed for foreign extractive firms (for example, multinational oil companies) to publish what they pay to host governments. Third, NGOs have urged governments in mineralrich states to disclose all their transactions with foreign extractive firms and their expenditures. ${ }^{83}$ Finally, they have sought to increase opportunities for public involvement in deciding how revenues will be spent through advocating improved human rights protection and encouraging a free press. ${ }^{84}$ 
Campaigns such as "Publish What You Pay" ${ }^{85}$ are a primary example of such INGO-inspired efforts. Here, a coalition of over 200 INGOs and local nongovernmental organizations (LNGOs) are working to persuade foreign extractive firms to disclose all taxes, fees, royalties, and other payments made to the host governments in the countries where they operate. In order to monitor how these revenues are used, they are also pushing for full disclosure of compensation payments and community development funding. Their efforts have been at least partially successful. British Petroleum (BP), for example, agreed to post its production-sharing agreement with Azerbaijan on a website and make its social and environmental impact assessments available to the general public. ${ }^{86}$ Pressure from both INGOs and LNGOs has also persuaded the World Bank to create "the Extractive Industry Review" to carry out an evaluation between 2001-2003 of its role in supporting projects in the mineral sector and their impact on poverty alleviation..$^{87}$

The biggest success to date, however, may be the Chad Revenue Management Plan. In order to encourage transparency and public oversight over the use of Chad's anticipated windfalls, the World Bank has made funding to construct a pipeline to export oil from land-locked Chad to Cameroon contingent on the government meeting certain conditions, such as adopting a revenue management plan and social and environmental safeguards. One of the unique aspects of the World Bank's program in Chad is the large role for external monitoring by both societal actors (LNGOs) and foreign actors (INGOs, the World Bank, and foreign oil companies) to ensure that Chad's oil windfalls are directed towards poverty reduction programs and not wasted on non-income earning projects. ${ }^{88}$ Built into Chad's Revenue Management Plan are different oversight mechanisms such as the Revenue Oversight Committee, which is composed of representatives from both the government and civil society and is charged with verifying government compliance with the revenue management law. Because of international and local NGO pressure, the foreign oil companies operating in Chad have also agreed to independent scrutiny of their activities and are paying for an External Compliance Monitoring Group composed of members of civil society to monitor their adherence to an environmental management plan. ${ }^{89}$

However, there are limitations to relying primarily on external actors to build transparency, accountability, and public oversight. Pressure from IFIs, foreign companies, and INGOs is insufficient unless first, societal actorsparticularly local NGOs_-are empowered by institutional safeguards, such as freedom of assembly and free speech; second, both foreign and societal actors can hold government officials accountable for their actions; and third, all of the actors involved-most importantly government officials-have a mutual interest in promoting transparency and stamping out corruption. The presence of these three conditions has fostered transparency, accountability, and public oversight in Norway, for example, where well-developed political parties, independent oversight councils, and a long-standing national parliament have monitored both government spending and oil extraction contacts. Similarly, since the late 1980s an informed public in Alaska has utilized preexisting representative institutions to demand formal oversight (that is, citizen advisory councils) of the petroleum's industry's activities. ${ }^{90}$

Conversely, the absence of these three conditions appears to be undermining Chad's Revenue Management Plan. Thus far, there is good reason to be skeptical of both the government's commitment to this plan and the ability of IFIs to enforce it. Although Chad's president initially committed to using the first signing bonus "in the spirit of the Revenue Management Law," the World Bank was unable to prevent him from spending a large portion of this bonus ( $\$ 4.5$ million, or approximately 20 percent) to purchase weapons. ${ }^{91}$ There is also good reason to doubt the foreign oil companies' commitment to the World Bank program. For example, INGOs are already highly critical of the oil companies' decision to put pipeline construction ahead of the social and environmental programs that are intended for poverty alleviation and increasing public involvement. ${ }^{92}$ Finally, in the absence of institutionalized mechanisms of responsiveness in Chad, LNGOs may find themselves solely targeting the foreign oil companies and the IFIs rather than engaging in a fruitful dialogue with the government over management of the petroleum industry's activities and windfall rents.

\section{Direct distribution}

Despite the tacit acknowledgement that the state is a large part of the problem, none of the most popular solutions attempt to take the mineral rents out of direct state control. The only exception is direct distribution of windfall revenues to the population, which has very recently been proposed as another way to avoid Dutch Disease effects, combat corruption, foster democratic governance, and even address the problem of weak institutions. ${ }^{93}$

The premise underlying this solution is that if the population receives the benefits of its natural resource wealth directly rather than through public works projects or state subsidies, it will make better investment choices and have a greater incentive to save these windfall rents than government officials. Some argue that direct distribution will also force the public to engage politically and demand oversight and accountability institutions to monitor the flow of petroleum revenue. ${ }^{94}$ Two forms of direct distribution have been put forth: the first is based upon the Alaska model in which the interest from the oil fund is directly distributed to the population ${ }^{95}$ whereas the second eliminates the use of a savings and stabilization fund. ${ }^{96}$ For countries like Nigeria and Iraq where government 
officials have siphoned off oil rents for personal profit and suppressed all forms of political resistance for decades, the idea of spreading the wealth among the population is especially attractive.

Yet, direct distribution schemes are not without their problems. For example, if direct access to "easy money" encourages myopic behavior on the part of government officials, there is no reason to believe that it will not induce the same spending effects on an individual-particularly one living below the poverty line. There is also the danger that transferring windfalls to individuals will reduce incentives for citizens to engage in entrepreneurship, which will further stifle the growth of small and medium private enterprises in developing countries. The case of Alaska, in which the population receives an annual dividend from oil and gas proceeds via mandatory state investments in the Alaska Permanent Fund, provides a striking illustration. The transfer of rents to households has fostered an environment in which the population is focused primarily on consumption, rather than investment. ${ }^{97}$ It has also had such a negative impact on the development of the private sector that several state-sponsored organizations have emerged to encourage entrepreneurialism among young Alaskans. ${ }^{98}$

Even where we might expect individuals to distribute rents most efficiently, such as rents generated from peasant cash crops, the empirical evidence to date suggests otherwise. For example, although small landholders in Kenya were able to save much of the windfalls generated from the coffee boom between 1976-79 (approximately 60 percent), government controls that favored the urban sector over the rural one prevented them from investing their savings efficiently. ${ }^{99}$

In contrast to the aforementioned solutions, direct distribution is viewed as a way to encourage institution building in mineral-rich states, particularly fiscal institutions, because the state would no longer be either the sole or the largest recipient of natural resource rents. ${ }^{100}$ It would also lack the fiscal autonomy from its population that rentier states enjoy. As a result, it would be compelled to develop a workable taxation system in order to collect revenue from its citizens. In reality, however, under existing and proposed models of direct distribution the government continues to be the largest direct beneficiary of the revenue from natural resource exports, ${ }^{101}$ and thus, suffers from the same disincentives for fiscal discipline. The failure of direct distribution models to specify who will be responsible for the dispersal of the proceeds to the population, and hence, how to ensure that the government does not either mismanage or appropriate the revenue, moreover, limits their efficacy-especially if the state continues to own and control the production and sale of petroleum reserves.

Alaska's experience again serves to illustrate. In Alaska, the state budget is the largest beneficiary of the proceeds from natural resources. The state is required to deposit only 25 percent of the royalties it collects from the oil sector into the Permanent Fund and the interest is divided evenly among the population. ${ }^{102}$ Much like petroleumrich countries in the developing world, therefore, the Alaskan government has had little incentive to develop a broadbased tax system; for example, it has neither introduced a personal income tax nor broad based sales tax. As a result, the relationship between the government and its citizens is defined solely by the "government [distributing] checks to citizens instead of citizens sending checks to government." ${ }^{103}$ The state government also has a chronic budget deficit because it must maintain high spending levels to satisfy constituents, who prefer to maintain the dividend program rather than use the Permanent Fund to balance the budget. In the 1980s, for example, Alaska's per capita state spending was far above the national norm and included public work projects that cost millions of dollars, yet never came to fruition. ${ }^{104}$ Direct distribution, then, seems to inadvertently reinforce a rentier mentality whereby the population views the government as a source of wealth distribution and the government is unable to demand fiscal compliance.

In addition, direct distribution shares the central problem of the aforementioned solutions because it requires a degree of institutional capacity that most resource-rich countries simply do not possess. At a bare minimum, it requires a viable banking system to distribute the revenues. This is not sufficient, however, to prevent government officials from engaging in rent-seeking or to curb corruption. Thus, in order to promote its perceived benefits, direct distribution also requires the same types of strong institutions as NRFs - that is, institutions that emphasize oversight, transparency, and accountability. Perhaps this is why, thus far, it has only been tried in a developed democracy with an effective bureaucracy like the United States. Yet, its success is questionable even there.

\section{The Missing Link: Private Ownership and State Capacity}

In sum, these existing solutions have largely failed because making the state a better "manager" of its mineral wealth requires institutions that promote transparency, accountability, and oversight - that is, institutions that are widely absent in developing countries. ${ }^{105}$ In contrast, we propose a solution that deliberately addresses the core problem of weak institutions - private domestic ownership.

Robust institutions are the product of both supply and demand; governments must have an incentive to supply them and societal actors must have both the interest and ability to make a credible demand for them. In the majority of mineral-rich states in the developing world, however, neither condition is met. State ownership in particular creates a disincentive for supplying institutions that would limit the government's fiscal independence or discretionary 
Figure 1

Variation in the Structure of Ownership, 1900-2000 ${ }^{1}$

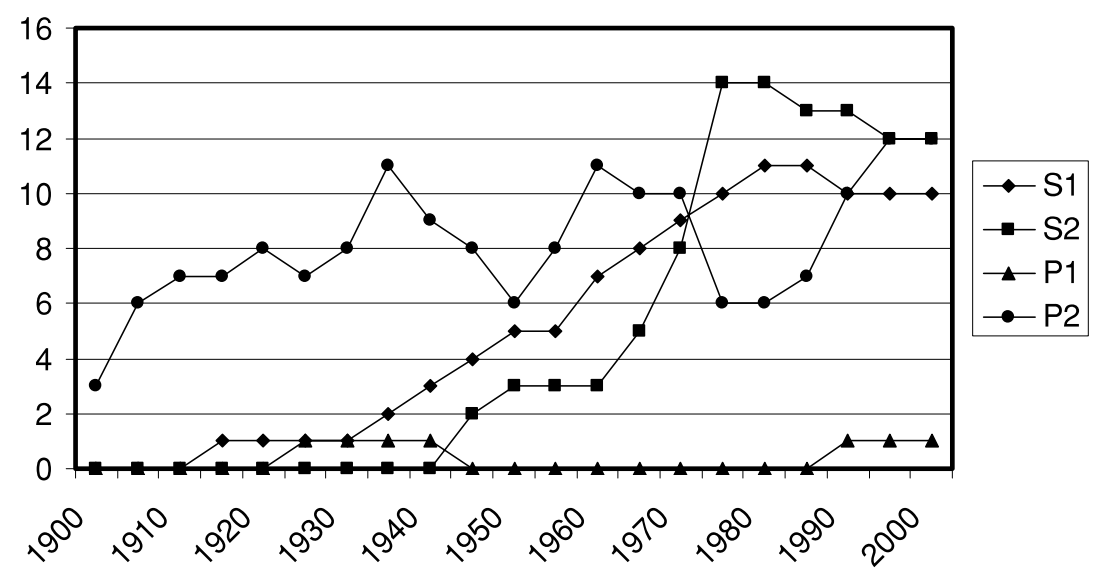

${ }^{1}$ This graph is based on the authors' preliminary codings for a subset (35) of petroleum-rich countries in the developing world: Algeria, Angola, Argentina, Azerbaijan, Brazil, Cameroon, Colombia, Republic of Congo, Ecuador, Egypt, Gabon, Guatemala, Indonesia, Iran, Iraq, Kazakhstan, Kuwait, Libya, Malaysia, Mexico, Nigeria, Oman, Peru, Qatar, Romania, the Russian Federation, Saudi Arabia, the Soviet Union, Sudan, Tunisia, Turkmenistan, U.A.E. (Abu Dhabi), Uzbekistan, Venezuela and Yemen.

decision-making power. It also undermines the development of societal actors that are either powerful enough to challenge the state or have a keen interest in limiting its power. Not surprisingly, then, the vast majority of mineralrich countries exercised state ownership over their mineral reserves from the late 1960 s to the early 1990 s - the very historical time period on which most of the literature on the resource curse focuses (see fig. 1).

By taking resource rents out of the state's direct control, privatization to domestic owners simultaneously fosters the conditions under which governments have an incentive to build strong fiscal and regulatory institutions and creates a new set of societal actors with the potential to demand these institutions. Because these private owners benefit directly from the production and export of the country's mineral reserves, they have a vested interest in securing both their property rights and a stable revenue stream as well as the means to bring state actors to the bargaining table. At the same time, because the state has less control over how these resources are extracted and utilized, it is more likely to invest in institution building that enables it to extract revenue from private owners, regulate the private sector, and generate other sources of revenue outside the natural resource sector. Thus, privatization to domestic actors offers an alternative path out of the "resource curse" because it creates an incentive for both state and societal actors to bargain over and eventually establish the formal rules of the game.

Russia provides a powerful illustration of this proposition. In the mid-1990s, Russia began privatizing its oil sector to domestic investors but retained state control over the gas sector. ${ }^{106}$ Since then, the degree of reform and economic promise in these two leading sectors has diverged significantly. By the end of 1990s, the majority of the oil industry was privatized to multiple owners, substantially deregulated, and had undergone significant internal restructuring. Under private ownership, the Russian oil industry has successfully expanded production and seen its net profits jump to $\$ 25$ billion in $2003 .{ }^{107}$ In addition, the domestic owners that emerged from this process have increasingly pressured the Russian government not only to support greater liberalization within the energy sector itself, but also to develop institutions outside the energy sector to promote greater transparency and fiscal stability. The gas sector, in contrast, continues to be dominated by the primarily state-owned monopoly Gazprom, which has resisted any structural reform, amassed substantial foreign debt, and remained chronically undercapitalized, translating into direct losses to the Russian economy and indirect losses to the institutional capacity of the Russian state.

\section{Why ownership matters}

Why should we expect state and private ownership to result in such distinct institutional outcomes? In short, because they foster a very different relationship between the main actors they generate. While both sets of actors under state ownership (that is, state elites and bureaucrats) and private ownership (that is, state elites and domestic owners) are relatively symmetrical in their ability to exert influence over the other, the boundaries between them are blurred and clear, respectively. These boundaries, in turn, promote very different incentives for institution building because they impose very different transaction and monitoring costs for the actors involved.

Under state ownership, the boundary between the main actors - state elites and bureaucrats—is blurred because there is no clearly identifiable principal. ${ }^{108}$ Rather, the population as a whole is the nominal principal whose interests are ostensibly served by a multitude of agents. At the same time, because the control structure is not clearly defined and there are no objective criteria for determining managerial performance, these agents often act like principals such that administrative tasks and political goals also become blurred. ${ }^{109}$ The relative power between state elites and bureaucrats is symmetrical because both have direct access to the proceeds from mineral exploitation. They also both have exclusive access to 
information about the income-as well as the misdeeds - of the other.

In the case of the Russian gas sector, for example, it is difficult to distinguish the management from the government. For most of the 1990s, Gazprom's president and board of directors not only controlled their own shares but also were entrusted with the government's shares. Thus, they openly ran the company as if they owned it. Then, as now, the Gazprom CEO is a presidential appointee and Gazprom's managers and government representatives form a majority on the board of directors. As a result, some have suggested that it has been hard to determine where "Gazprom ends and the Russian state begins." 110

Blurred boundaries reduce transaction and monitoring costs by making revenue readily available to multiple principals, all of whom are charged with managing this revenue but none of whom can benefit directly when it is generated efficiently. In most developing countries, for example, petroleum resources are managed through a state oil company. Bureaucrats are assigned to run the company on behalf of the state, with the understanding that the company —and most importantly, its income-ultimately falls under the jurisdiction of the state elites. ${ }^{111}$ These bureaucrats not only have a greater opportunity to steal from the company but also a greater incentive to do so because, as de facto government employees, they are not compensated for performance. Because they have no direct claim to the residual (or profits), they also have a greater incentive to operate the company without regard for profitability. ${ }^{12}$ This is reinforced by soft budget constraintsthat is, continued access to state revenue, regardless of whether or not the company is profitable.

As a result, state elites and bureaucrats share incentives for building or sustaining weak institutions. Both prefer greater discretionary power, and thus, institutions that are unlikely to constrain their behavior in any meaningful or predictable way. Neither side has an incentive to support the development of institutions that foster internal and external oversight mechanisms, increase transparency, or impose hard budget constraints. Rather, because both sides have direct access to the proceeds from the exploitation of the energy sector, they prefer greater discretionary power and informal agreements over the allocation and use of these proceeds. This encourages a form of implicit bargaining whereby each side tacitly agrees to either undermine existing institutions that might pose a threat to their discretionary authority, for example, by increasing transparency and accountability, or to maintain the status quo, and thus neglect institution building altogether. These tendencies are likely to be exacerbated, moreover, by an exogenous shock or economic crisis because time horizons shorten and opportunities for rent-seeking expand.

The blurred boundary between the state and Gazprom, for example, has benefited both sides. On the one hand, it has empowered the gas sector to operate with very little internal or external scrutiny over its transactions. For example, during most of the 1990s, the Russian Audit Chamber did not demand an official audit of Gazprom's finances. This lack of oversight is evident in Gazprom's notorious mismanagement of investment funds and arbitrary transfer of assets to board members and relatives during Boris Yeltsin's presidency. ${ }^{113}$ Gazprom's integrated structure also provides the company with a relatively costless and effortless way of hiding its profits, and thus lining its managers' pockets.

On the other hand, this blurred boundary has enabled the Russian government to utilize its leverage as the ultimate owner to fulfill its domestic fiscal and spending requirements. Gazprom remains subjected to price controls and delivery requirements for nonpaying domestic customers, which account for a large portion of its implicit tax burden. As a result, Gazprom is forced to sell most of the gas it produces (70 percent) on the domestic market for approximately 15 percent of the price it would receive on the global market. Combined with the high rate of tariff arrears in Russia among industrial and household consumers alike, therefore, it is not surprising that Gazprom operates at a loss. ${ }^{114}$ Nonetheless, the government has refused to lower Gazprom's explicit tax burden, contributing further to its well-earned position as Russia’s largest taxpayer. ${ }^{115}$ Gazprom's explicit tax burden has actually increased following the August 1998 financial crisis and the adoption of a new tax code in 2000-2001. Meanwhile, its implicit tax burden has also steadily increased as government officials utilize Gazprom's budget for social and political goals such as financing election campaigns. ${ }^{116}$

Yet, the long-term costs of weak fiscal, regulatory, and supervisory institutions outweigh the short-term benefits to each side. In sum, the blurred boundary has created and reinforced an informal agreement whereby Gazprom's managers accept a high tax burden in exchange for the ability to line their own pockets and the government accepts less transparency and accountability for virtually unlimited access to Gazprom's coffers. This has resulted in a net economic loss for both Gazprom as a company and the Russian economy as a whole. "Years of asset stripping and lack of transparency," for example, are responsible for Gazprom's gross undercapitalization. ${ }^{117}$

Under private domestic ownership, in contrast, the boundary between the main actors — state elites and domestic owners-is clear because there is a clearly identifiable principle. Because the control structure is clearly defined and there are objective criteria for evaluating managerial performance, agents do not conflate administrative tasks with political goals. Rather, they are punished and rewarded based on their ability, for example, to maximize efficiency, increase profits and market capitalization, and expand market share. Their relative power is symmetrical because each has an independent source of authority over the other. Domestic owners possess the rights to revenue from mineral 
exploitation, and thus, are a critical source of tax revenue for the state. State elites possess the authority to revoke property rights and reduce revenue streams through demanding excessive taxation. In short, they need each other not just to survive, but also to thrive.

Clear boundaries increase transaction and monitoring costs by simultaneously making it more difficult for state elites to extract revenue and for private owners to hide their income. During Yeltsin's presidency (1991-98), for example, the government was forced to either confiscate revenue from the oil companies or to engage in continuous bargaining over revenue burdens. ${ }^{118}$ Also during this period, the Russian oil companies (hereafter, ROCs) devised several legal and semi-legal schemes to reduce their profitability on paper that eventually proved too costly-not only because it required expending effort and finances on nonproductive activities but also because it earned them a lower stock market valuation. ${ }^{119}$

Clear boundaries also make it less rational to steal. Unlike state companies, in private companies managers are compensated based on performance and the owners have a direct claim to profits, and thus, both owners and managers are primarily concerned with profitability. Ownersincluding shareholders with a minority stake (that is, 25 percent of the shares) ${ }^{120}$ —also have a vested interest in ensuring that both their managers and employees do not steal or otherwise jeopardize the company's financial health. When these minority shareholders are multinational corporations (MNCs), moreover, they can also provide further defense against state predation because they carry the added weight of access to capital, international arbitration, and foreign governments to both deter and challenge such practices.

Nor can private companies necessarily rely on the state to bail them out if they are operating at a loss. Hard budget constraints and the fear of bankruptcy thus reinforce the desire of owners and managers to run the company efficiently. As a result, they are unlikely to invest in unproductive public work projects or provide subsidies-tasks that a government often demands of state-owned companies to promote its own social and political objectives.

High transaction and monitoring costs, therefore, promote mutual incentives for building stable, effective, and far-reaching institutions - that is, strong institutions. Both state elites and private actors, for example, prefer a tax regime that is stable, so as to ensure fiscal predictability, and one that is broad-based, so as to decrease the state's fiscal reliance on the mineral sector. Both also prefer regulatory institutions that will effectively monitor companies' profits and employees. The main actors' interests concerning institution building thus converge. Yet, their preferences over the exact content of these institutions (for example, tax rates, number of audits, and so forth) will vary based on their specific interests. Combined with the fact that their relative power is symmetrical (that is, neither can impose their preferred outcome on the other), this variation in preferences over content encourages these two sets of actors to engage in explicit bargaining to formulate strong institutions. The mutual desire for formal guarantees is likely to be reinforced, moreover, by an exogenous shock or economic crisis because both actors will feel vulnerable and their continued survival will depend more acutely on the actions of the other.

The mutual desire for fiscal predictability following the August 1998 financial crisis, for example, provided the impetus for the Russian government and private domestic oil companies to negotiate a broad-based tax code that was enacted between 1999-2002. ${ }^{121}$ By most accounts, this new tax code exceeds Western standards-not only because it sets lower tax rates than the OECD recommends but also because it is much simpler and clearer than the previous one. Most important, the new tax code has resulted in an increase in the contribution of the personal income tax to the budget. ${ }^{122}$ Foreign and domestic financial and political analysts alike have also praised the new tax code for the inclusive nature of tax benefits, and thus, its potentially positive impact on the Russian economy as a whole. The increased tax collection rates since the new code was put into effect support this optimism. In 2004 alone, for example, Russias federal budget recorded a 17.7 percent increase in tax revenue. ${ }^{123}$

The financial crisis also motivated the ROCs to alter significantly their prior behavior and to design forwardlooking development strategies. ${ }^{124}$ Whereas governments across mineral-rich countries in which the oil sector is under state ownership commonly respond to economic crises linked to sharp declines in the market price of petroleum (or commodity "busts") by increasing production to make up for budgetary shortfalls, thereby lowering their profits, and/or by borrowing against future expected revenues, ${ }^{125}$ the ROCs did neither. Nor did they pool their lobbying efforts or resources to seek state protection or "capture" the policy process, as Michael Shafer ${ }^{126}$ and others would have predicted. ${ }^{127}$ Rather, the ROCs consciously and successfully adjusted to the current bust and prepared for future booms by concentrating their efforts on cleaning up their internal operations so as to get their finances in order and finding ways to increase both production and profits over the long-term.

A central component of this adjustment strategy consisted of building foreign partnerships through attracting minority shareholders from abroad and/or bringing in foreign management. ${ }^{128}$ This has had several undeniably positive effects on the development of the Russian oil industry. First, the ROCs' desire to attract foreign capital, and consequently to increase share prices, bolstered their commitment to greater transparency and corporate governance. Indeed, hiring foreign managers was a conscious attempt to signal this commitment to shareholders, as well as the Russian government. ${ }^{129}$ Second, bringing foreign expertise 
and capital directly into their respective enterprises enabled the ROCs to invest in new technology to increase production by tapping into old (brown) wells-a strategy that was both technologically impossible and highly unpopular among neftyaniki (oilmen) during the late Soviet period. Several of the ROC representatives and foreign investors we interviewed commented that Soviet-trained oilmen viewed this practice as "unmanly," preferring to open up new wells when oil did not easily flow from existing ones. Some of the ROCs also viewed foreign expertise and capital as a means to realize their ambitions to build new pipelines that would open up new markets-especially China-and provide an alternative to governmentcontrolled pipelines as a prelude to investment in exploring and developing new wells. Finally, many ROCs deliberately sought foreign partnerships in order to simultaneously expand their operations at home-in particular to the Northern Territories where exploration requires both more capital and advanced technology — and abroad so as to reduce their future dependence on domestic reserves. By 2001, for example, Lukoil had already teamed up with Conoco International to explore oil in Russias TimanPechora region ${ }^{130}$ and had approximately 40 percent of its operations in foreign markets. ${ }^{131}$

Thus while some Western analysts have criticized the ROCs failure to invest in exploration, and hence, the development of new oil wells, ${ }^{132}$ these efforts suggest a different picture. Combined, they indicate a strategy that is aimed not only at long-term investment but also at securing multiple sources of oil and access to new markets. On the one hand, these analysts and others have downplayed the ROCs attempts to explore new fields in the Far East, for which present production-sharing agreement (PSA) legislation privileges foreign investors. ${ }^{133} \mathrm{On}$ the other, they have overlooked the fact that the ROCs eventually want to be able to compete on the same playing field as other multinational oil companies, which requires looking beyond domestic production and existing markets.

\section{Conclusion}

In a recent op-ed, Joseph Stiglitz writes, "Abundant natural resources can and should be a blessing, not a curse. We know what must be done. What is missing is the political will to make it so." ${ }^{134}$ Scholars and policy makers alike have become increasingly convinced that it is possible to combat the resource curse through a broad array of policies that include natural resource funds, economic diversification, transparency and accountability, and direct distribution. These solutions, however, rely on a degree of institutional capacity that is widely absent in mineralrich countries, and thus they are prone to suffer from the aforementioned negative economic, political, and social outcomes.
In contrast, we offer a solution that directly addresses the pervasive problem of weak institutions in mineralrich states-privatization to domestic owners. By taking resource rents out of the state's direct control, domestic privatization simultaneously fosters the conditions under which governments have an incentive to build strong fiscal and regulatory institutions and creates a new set of societal actors with the potential to demand these institutions.

Domestic privatization, however, is not a short-term remedy for institutional weakness. Building institutions is a lengthy process, involving numerous conflicts between the government and domestic capitalists over their respective roles in the economy and the rules that define them. This process is also a highly political one and, as such, is often mired in the political priorities of the moment, which can temporarily derail economic ones.

Russia again serves to illustrate. In June 2003 various agencies within the Russian government launched an increasingly fierce assault against Yukos, which had become the largest and most profitable ROC by 2002 owing to the aforementioned strategic changes. ${ }^{135}$ This assault culminated in the arrest of Yukos's former CEO, Mikhail Khodorkovsky, and the forced sale of its most valuable subsidiary and covetable asset-Yuganskneftegaz ${ }^{136}$-on December 19, 2004, to cover unsubstantiated tax claims exceeding the company's revenue. Yet, while many analysts have interpreted the government's assault against Yukos as the death knell of private ownership in the oil sector, and thus, a calculated move toward regaining control over the country's most important economic assets, ${ }^{137}$ the overwhelming evidence indicates that the primary motivation was political and personal. ${ }^{138}$

First, Khodorkovsky openly flaunted his economic success-most notably through arranging the first shipments of Russian crude oil to the United States in the summer of 2002 and financially sponsoring opposition parties in the 2003 parliamentary elections - and used it to launch his own political career, suggesting that he would run for president in 2008. The state prosecutor's recent decision in March 2005 not to demand additional jail terms for Khodorkovsky and Platon Lebedev, Yukos's second largest shareholder, for their role in the illegal purchase of shares in Apatit, a fertilizer company, in 1994 has reinforced the political nature of government's case, given that in addition to alleged tax fraud, this was the main reason underlying their arrest. ${ }^{139}$

Second, the assault on Yukos has thus far been unique, both in form and content. It has not amounted to the renationalization of the oil sector, but rather, the partial dismantling of Yukos. As of the spring of 2005, no concrete action had been taken against Yukos's other subsidiaries, Tomskneft and Samaraneftegaz. If Yukos manages to retain these two subsidiaries, it would still be a major contender in the Russian oil industry. ${ }^{140}$ At the same time, 
other ROCs - particularly those with a formidable MNC partner ${ }^{141}$ - have escaped the degree of government predation that Yukos has experienced. While minority foreign ownership, perhaps because it only constituted 10 percent of the shares, did not prevent the government's assault against Yukos, minority shareholders in both this company and its single largest domestic investor, Menatep Bank, played a key role in foiling the Russian government's plan to buy Yuganskneftegaz outright via Gazprom's winning bid and seem to have stalled any further legal action against the company. ${ }^{142}$

Finally, the government has remained committed to private ownership and securing property rights, as evidenced by its decision to sell its remaining shares in Lukoil in $2004^{143}$ and Putin's recent initiative to provide legal protection for the various "insider privatizations" that occurred in the mid-1990s by reducing the statute of limitations on them from 10 years to three years. ${ }^{144}$ That this commitment is credible is evidenced by the fact that, despite the assault against Yukos, other ROCs have continued to increase their domestic investments. ${ }^{145}$

Domestic privatization is also not universally applicable. Like any policy prescription, the domestic context can be more or less conducive to its feasibility. First, state leaders are more likely to privatize their mineral sector where they are both able to rely on an alternative source of export revenue in the short-term and feel threatened by the emergence of a rival political cleavage. ${ }^{146}$ Transferring ownership of these resources from the state to private domestic actors thus becomes a way to bolster existing supporters and/or appease emerging rivals without the immediate need for attracting foreign capital. When privatization occurs in this manner, moreover, it is more likely to lead to the establishment of clear boundaries between those who own the resource (that is, domestic capitalists) and those who regulate it (that is, the state). Second, domestic privatization is more likely to succeed where domestic entrepreneurs have an interest in developing the mineral sector, as is clearly the case in Russia today as well as the United States in the late 1800s and Romania during the interwar period. ${ }^{147}$

While Stiglitz and others tend to view the problem of mineral wealth as a matter of political will alone, our research suggests that this approach fails to take the broader picture into account. Political will, like institutional capacity, is the product of incentives. Thus, even though domestic privatization can be a highly contentious process, it remains the only solution that can generate the incentives for governments in mineral-rich countries to both acquire the will and build the capacity to manage their resources effectively. Precisely because domestic capitalists own its mineral resources, rather than the state, Russia has the potential to build a brighter future than its mineral-rich counterparts in the developing world. International actors and organizations would therefore be well advised to advo- cate privatization to domestic owners as another possible solution for combating the resource curse, especially for new producers of mineral wealth like Azerbaijan, Kazakhstan, East Timor, Chad, and Sudan. With time and international support, they can pursue domestic privatization as a strategy and thereby create the necessary institutions to turn their mineral wealth into a blessing rather than a curse.

\section{Notes}

1 See, for example, Deffeyes 2003, Campbell 1997.

2 Gault 2002.

3 Klare 2004.

4 U.S. Department of Energy, Energy Information Administration (DoE/EIA) 2004.

5 Davis 1995 is the only exception.

6 Sala-I-Martin and Subramanian 2003, 3.

7 See, for example, Auty 1993, Auty and Gelb 2001, Sachs and Warner 1995.

8 Auty and Mikesell 1998.

9 See, for example, Wade 1990, World Bank 1993.

10 World Bank 2001a.

11 See, for example, Lewis 1984, Philip 1994.

12 World Bank 2004.

13 CIA 2003, World Bank 2004.

14 CIA 2003.

15 See, for example, Gylfason 2001a, Leite and Weidmann 1999.

16 This includes six indicators (Voice and Accountability, Political Stability and Lack of Violence, Government Effectiveness, Regulatory Quality, Rule of Law, and Control of Corruption) "based on 25 separate data sources at 18 different organizations, including the World Bank itself, Gallup International, the Economist Intelligence Unit, IMD, DRI/McGrawHill, Columbia University, Freedom House, Afrobarometer, Latinobarometro, the World Economic Forum, and Reporters Without Borders." World Bank 2003. Data available at http://www. worldbank.org/wbi/governance/data.html.

17 World Bank 2002, Transparency International 2004. CPI ranks countries according to the degree to which corruption is perceived to exist among public officials and politicians, ranging between 10 (highly clean) and 0 (highly corrupt). For more information, see http://www.transparency.org/surveys/ index.html\#cpi.

18 See, for example, Ross 2001b.

19 See, for example, Jensen and Wantchekon 2004.

20 See, for example, Wantchekon 1999, Smith 2004.

21 Ross 2001a, 356. Herb 2005, in contrast, argues that the negative effects of oil rents on democracy have been overestimated.

22 See, for example, Baldwin 1966, Hirschman 1958. 
23 See, for example, Lipset 1960, Deutsch 1961.

24 Gary and Karl 2003, 41.

25 See, for example, Sachs and Warner 1995.

26 See, for example, Birdsall et al. 2001, Gylfason $2001 b$.

27 See, for example, Auty 1990, Gelb and Associates 1988, McMahon 1997.

28 Ascher 1999, 179.

29 Sala-I-Martin and Subramanian 2003, 13.

30 See, for example, Auty 1990, Gelb and Associates 1988, Lewis 1984.

31 See, for example, Leite and Weidmann 1999, Khan 1994, Mauro 1995, and McMahon 1997.

32 Lane and Tornell 1997.

33 See, for example, Auty 1998.

34 Ascher 1999, 62.

35 Bradsher 2005.

36 Mikesell 1997.

37 Katz et al. 2004, 9-10.

38 Katz et al. 2004, 10, McMahon 1997.

39 Sarraf and Jiwanji 2001, 7.

40 Gelb 1985, 76.

41 Philip 1994, 12.

42 A rent is "a return in excess of a resource owner's opportunity costs" (Tollison 1982, 575); in the case of mineral-exporting countries, these returns are thus generated from foreign sources.

43 See, for example, Karl 1997, Mitra 1994.

44 See, for example, Beblawi and Luciani 1987, Karl 1997.

45 Beblawi and Luciani 1987, Delacroix 1980.

46 See, for example, Beblawi and Luciani 1987.

47 See, for example, Shafer 1994, Karl 1997.

48 See, for example, Anderson 1987, Chaudhry 1989, Karl 1997.

49 Crystal 1989, 434.

50 Karl 1997, 16.

51 Shafer 1994.

52 Crystal 1989.

53 See, for example, Karl 1997, Ross 2001c, Shafer 1994, Teichman 1988.

54 Wantchekon 1999.

55 See, for example, Bellin 2004, Smith 2004.

56 See, for example, Clark 1997 and Karl 1987.

57 Karl 1997, 139.

58 Ascher 1999, Ross 2001a.

59 Karl 1997, Shafer 1994, Chaudhry 1989.

60 Dutch Disease effects may even begin before the windfalls flow with the influx of foreign investment into the mineral sector.

61 Katz et al. 2004.

62 Sarraf and Jiwanji 2001.

63 Sarraf and Jiwanji 2001.

64 See, for example, Stevens 2003, Gelb and Associates 1988, Eifert et al. 2003.
65 See, for example, Alesina et al. 1996.

66 Sarraf and Jiwanji 2001, 12.

67 See, for example, Katz et al. 2004, Sarraf and Jiwanji 2001.

68 See, for example, Davis 1995, Sachs and Warner 1995.

69 See, for example, Auty 1990, Gelb 1985.

70 See, for example, Auty 1993, Sachs and Warner 1995, Gylfason 2001a.

71 See, for example, Lewis 1984.

72 Davis 1995.

73 Auty 2001, 142.

74 See, for example, Gelb and Associates 1988, Usui 1997.

75 Davis et al. 2003.

76 Davis et al. 2003.

77 See, for example, Kasson 1983.

78 Eifert et al. 2003.

79 Tsalik 2003.

80 Authors' interview with State Oil Fund, Azerbaijan, 2002.

81 Friends of the Earth 2002.

82 Gary and Karl 2003.

83 Tsalik 2003, Save the Children 2003, Gary and Karl 2003.

84 Ross 2001b, Gary and Karl 2003.

85 For details, see www.publishwhatyoupay.org.

86 Authors' interview, Baku, Azerbaijan, 2002.

87 Details available at http://www.eireview.org.

88 McPherson 2002, Gary and Karl 2003.

89 Gary and Karl 2003.

90 Steiner 2003.

91 World Bank 2001b.

92 See, for example, Gary and Karl 2003, Global Policy Forum 2003.

93 Birdsall and Subramanian 2004, Sala-I-Martin and Subramanian 2003, Palley 2003.

94 See, for example, Palley 2003.

95 See, for example, Birdsall and Subramanian 2004.

96 See, for example, Sala-I-Martin and Subramanian 2003.

97 Goldsmith 2001, 12.

98 See, for example, http://alaskainvestnet.org.

99 See, for example, Bevan et al. 1987.

100 See, for example, Sala-I-Martin and Subramanian 2003.

101 See, for example, Birdsall and Subramanian 2004.

102 For details, see Goldsmith 2001.

103 Goldsmith 2001, 5.

104 Jackstadt and Lee 1990.

105 It is worth mentioning here that our portrayal of effective state institutions differs from the large and distinguished literature on the "developmental state." The latter focuses on the need for a competent state bureaucracy for promoting 
industrialization and export-led growth. See, for example, Wade 1990, Evans 1995, Kohli 2004.

106 Comparing the oil and gas sector within Russia (as opposed to oil sectors in two different countries) also allows us to control for national level variation, and thus to isolate ownership structure as the key explanatory variable.

107 Russia Journal, May 19, 2004.

108 See, for example, Aharoni 1982.

109 See, for example, Boycko et al. 1996, Shleifer and Vishny 1994.

110 Rutland 1997, 8.

111 This is not the case where state oil companies are effectively monitored by a third party, such as the parliament or an independent regulatory agency, as is the case with Statoil in Norway. These institutions tend to either not exist or be ineffective, however, in developing countries.

112 On "residual claimant" theory, see Alchian and Demsetz 1972.

113 See, for example, Hoffman 2000, A01.

114 See, for example, Observer 09/02/2003.

115 Agafonov 2003.

116 See Weinthal and Jones Luong forthcoming for details.

117 Washington Post, June 23, 2002.

118 See Jones Luong and Weinthal 2004 for details.

119 See Jones Luong and Weinthal 2004 for details.

120 The 25 percent threshold is crucial because it allows them to block any major decision, such as the transfer of assets.

121 See Jones Luong and Weinthal 2004 for details.

122 Aslund 2001, 22.

123 Russia Journal, January 25, 2005.

124 Authors' interviews with representatives from both Russian and foreign oil and gas companies, Russian government officials, and Russian and foreign financial and energy experts, Moscow, September 2001 and July 2002.

125 It is interesting to note that many scholars attribute this common failure to respond to busts to weak institutions in resource-rich states. See, for example, Chaudhry 1989 and Shafer 1994.

126 Shafer, 1994.

127 See Jones Luong and Weinthal 2004 for details. Although they have similar interests, as direct competitors and possibly intense rivals, private owners are unlikely to rely on collusion to exert influence. In attempting to work together in order to pressure the government for favorable policies, therefore, even a small number of actors face a considerable collective action problemparticularly in a fluid context such as Russia. See, for example, Olson 1982.

128 Authors' interviews (op. cit.).
129 See Jones Luong and Weinthal 2004 for details.

130 Authors' interview with Eric Bell, President, Conoco International Petroleum Company, Moscow, September 20, 2001.

131 Author's interview with Konstantin Reznikov, Alfa Bank, Senior Oil and Gas Analyst, Moscow, September 19, 2001.

132 See, for example, Dienes 2004, Hill 2004.

133 Authors' interviews (op. cit.).

134 Stiglitz 2004.

135 See Weinthal and Jones Luong forthcoming for details.

136 Yuganskneftegaz accounts for two-thirds of Yukos's and approximately 11 percent of Russia's total oil production.

137 See, for example, Goldman 2004, Hill 2004.

138 Indeed, our comprehensive survey of the Russian language press from June 2003 to August 2004, which we do not have the space to present here, indicates that this is the consensus among Russian analysts.

139 In his decision, the state prosecutor cited the 10year statute of limitations. Faulconbridge 2005.

140 Korchagina 2004.

141 This is true, for example, of the ROC Tyumenskaia Neftianaia Kompaaniia (TNK), which partnered with British Petroleum in 2003.

142 The fear of a lengthy (and high-profile) legal battle propelled a consortium of international banks to withdraw their financial support for Gazprom's bid and the Russian government to come up with an elaborate scheme to find another Kremlin-friendly buyer. See, for example, Belton 2004.

143 Radio Free Europe/Radio Liberty (RFE/RL); back issues can be accessed at http://search.rferl.org/. September 29, 2004.

144 Granville and Lissovolik 2005. Russia's "insider privatization" refers to its controversial privatization program in the 1990s that allowed those with close ties to the Kremlin to gain control over the state's most important strategic resources.

145 Moscow Times, April 7, 2005.

146 See Jones Luong and Weinthal 2001 for details.

147 In contrast, domestic capitalists in Colombia refused the government's offer to take on the development of oilfields (Kline 1995). In Venezuela they quickly sold off their oil fields to foreign companies in order to pursue other economic interests (Lieuwen 1954).

\section{References}

Agafonov, Anton. 2003. Restructuring of Gazprom: Political rationale prevails. New Energy Group Online. 
April 24. http://www.newenergyanalytics.com/ reports/index.phtml?234.

Aharoni, Yair. 1982. State-owned enterprise: An agent without a principal. In Public enterprise in lessdeveloped countries, ed. Leroy P. Jones, 67-76. Cambridge and New York: Cambridge University Press.

Alchian, Arman A., and Harold Demsetz. 1972. Production, information costs, and economic organization. American Economic Review 62 (5): 777-95.

Alesina, Alberto, Richardo Hausmann, Rudolf Holmes, and Ernesto Stein. 1996. Budget institutions and fiscal performance in Latin America. National Bureau of Economic Research Working Paper 5586.

Anderson, Lisa. 1987. The state in the Middle East and North Africa. Comparative Politics 20 (1): 1-18.

Ascher, William. 1999. Why governments waste natural resources: Policy failures in developing countries. Baltimore: Johns Hopkins University Press.

Aslund, Anders. 2001. Russia. Foreign Policy. July/ August: 20-25.

Auty, Richard M. 1990. Resource-based industrialization: Sowing the oil in eight developing countries. Oxford: Oxford University Press.

- 1993. Sustaining development in mineral economies: The resource curse thesis. London and New York: Routledge.

- 1998. Resource abundance and economic development: Improving the performance of resource-rich countries. Helsinki: The United Nations University World Institute for Development Economics Research.

- 2001. Resource abundance and economic development. Oxford: Oxford University Press.

Auty, Richard M., and Alan H. Gelb. 2001. Political economy of resource abundant states. In Resource abundance and economic development, ed. Richard Auty. 126-44. Oxford: Oxford University Press.

Auty, Richard M., and Raymond F. Mikesell. 1998. Sustainable development in mineral economies. Oxford: Claredon Press.

Baldwin, Robert E. 1966. Economic development and export growth. Berkeley: University of California Press.

Beblawi, Hazem, and Giacomo Luciani, eds. 1987. Nation, state and integration in the Arab world. Vol. 2, The rentier state. London: Croom Helm.

Bellin, Eva. 2004. The robustness of authoritarianism in the Middle East: Exceptionalism in comparative perspective. Comparative Politics 36 (2): 139-57.

Belton, Catherine. 2004. Yukos accused of "filthy theft." Moscow Times, December 14.

Bevan, David L., Paul Collier, and Jan Willem Gunning. 1987. Consequences of a commodity boom in a controlled economy: Accumulation and redistribution in Kenya 1975-83. World Bank Economic Review 1 (3): 489-513.
Birdsall, Nancy, and Arvind Subramanian. 2004. Saving Iraq from its oil. Foreign Affairs (July/August): 77-89. Birdsall, Nancy, Thomas Pinckney, and Richard Sabot. 2001. Natural resources, human capital, and growth. In Resource abundance and economic development, ed. Richard M. Auty, 57-75. Oxford: Oxford University Press.

Boycko, Maxim, Andrei Shleifer and Robert Vishny. 1996. A theory of privatization. Economic Journal 106: 309-19.

Bradsher, Keith. 2005. Oil wealth wasting away in Indonesia. New York Times, March 19.

Campbell, Colin J. 1997. The coming oil crisis. Essex, UK: Multi-Science Publishing.

Central Intelligence Agency (CIA). 2003. World factbook 2003. Washington, DC: Central Intelligence Agency.

Chaudhry, Kiren Aziz. 1989. The price of wealth: Business and state in labor remittance and oil economies. International Organization 43 (1): 101-45.

Clark, John 1997. Petro-politics in Congo. Journal of Democracy 8 (3): 62-76.

Crystal, Jill. 1989. Coalitions in oil monarchies: Kuwait and Qatar. Comparative Politics 21 (4): 427-43.

Davis, Graham. 1995. Learning to love the Dutch disease: Evidence from the mineral economies. World Development 23 (10): 1765-79.

Davis, Jeffrey, Rolando Ossowski, James A. Daniel, and Steven Barnett. 2003. Stabilization and savings funds for nonrenewable resource experience and fiscal policy implications. In Fiscal policy formulation and implementation in oil-producing countries, ed. Jeffrey Davis, Rolando Ossowski, and Annalisa Fedelino, 273-315. Washington DC: IMF.

Deffeyes, Kenneth S. 2003. Hubbert's peak: The impending world oil shortage. Princeton: Princeton University Press.

Delacroix, Jacques. 1980. The distributive state in the world-system. Studies in Comparative International Development 15 (3): 3-21.

Deutsch, Karl. W. 1961. Social mobilization and political development. American Political Science Review 55 (3): 493-514.

Dienes, Leslie. 2004. Observations on the problematic potential of Russian oil and the complexities of Siberia. Eurasian Geography and Economics 45 (5): 319-45.

Eifert, Benn, Alan Gelb, and Nils Borje Tallroth, 2003. The political economy of fiscal policy and economic management in oil-exporting countries. In Fiscal policy formulation and implementation in oil-producing countries, ed. Jeffrey Davis, Rolando Ossowski, and Annalisa Fedelino, 82-122. Washington DC: IMF.

Evans, Peter. 1995. Embedded autonomy: State and industrial transformation. Princeton: Princeton University Press. 
Faulconbridge, Guy. 2005. Prosecutors go for the full 10 years. Moscow Times, March 30.

Friends of the Earth. 2002. Oil funds: Answer to the paradox of plenty? November.

Gary, Ian, and Terry Karl. 2003. Bottom of the barrel: Africa's oil boom and the poor. Catholic Relief Services.

Gault, John. 2002. The European Union: Energy security and the periphery. Occasional Paper Series, No. 40. Geneva Centre for Security Policy. http://www. gcsp.ch/e/publications/Other-pubs/Occ-papers/2002/ 40-Gault.pdf

Gelb, Alan H. 1985. Adjustment to windfall gains: A comparative study of oil-exporting countries. In Natural resources and the macroeconomy, ed. J. Peter Neary and Sweder van Wijnbergen, 54-95. Cambridge: MIT Press.

Gelb, Alan H., and Associates. 1988. Oil windfalls: Blessing or curse? New York: Oxford University Press.

Global Policy Forum. 2003. Chad-Cameroon: Oil and poverty reduction don't mix. May-June. http:// www.globalpolicy.org/security/natres/oil/2003/ 0503mix.htm

Goldman, Marshall I. 2004. Putin and the oligarchs. Foreign Affairs 83 (6): 33-44.

Goldsmith, Scott. 2001. The Alaska permanent fund dividend program. Paper presented at the conference on Alberta: Government Policies in a Surplus Economy, University of Alberta. Edmonton, Alberta, September 7.

Granville, Christopher and Yaroslav Lissovolik. 2005. Dusting off a difficult amnesty. Moscow Times, March 30.

Gylfason, Thorvaldur. 2001a. Nature, power, and growth. Journal of Political Economy 48 (5): 558-88.

- 2001b. Natural resources, education, and economic development. European Economic Review 45: 847-59.

Herb, Michael. 2005. No representation without taxation? Rents, development, and democracy. Comparative Politics 37 (3): 297-317.

Hill, Fiona. 2004. Energy empire: Oil, gas, and Russia's revival. London: Foreign Policy Centre.

Hirschman, Albert O. 1958. The strategy of economic development. New Haven: Yale University Press.

Hoffman, David. 2000. Foreign investors criticize deals by Russian gas giant. Questions about asset transfers may provide challenge to Putin. Washington Post Foreign Service, December 24.

Isham, Jonathan, Michael Woolcock, Lant Pritchett, and Gwen Busby. April 2003. The varieties of resource experience: How natural resource export structures affect the political economy of economic growth. Middlebury College Economics Discussion Paper No. 03-08.
Jackstadt, Stephen L., and Dwight R. Lee 1990. Alaska’s other oil spill. The Freeman 40 (1).

Jensen, Nathan and Leonard Wantchekon. 2004. Resource wealth and political regimes in Africa. Comparative Political Studies 37 (7): 816-41.

Jones Luong, Pauline and Erika Weinthal. 2001. Prelude to the resource curse: Explaining oil and gas development strategies in the Soviet successor states and beyond. Comparative Political Studies 34 (4): 367-99.

- 2004. Contra coercion: Russian tax reform, exogenous shocks and negotiated institutional change. American Political Science Review 98 (1): 139-52.

Karl, Terry Lynn. 1987. Petroleum and political pacts: The transition to democracy in Venezuela. Latin American Research Review 22 (1): 63-94.

Karl, Terry Lynn. 1997. The paradox of plenty: Oil booms and petro-states. Berkeley: University of California Press.

Kasson, Joan. 1983. The creation of the Alaska permanent fund. In Perspectives on the origins of Alaska's oil savings account: The trustees' papers volume no. 5, February, 1997. http://www.apfc.org/publications/ tp5.cfm?s=5.

Katz, Menachem, Ulrich Bartsch, Harinder Malothra, and Milan Cuc, 2004. Lifting the oil curse: Improving petroleum revenue management in Sub-Saharan Africa. Washington, DC: IMF.

Kaufmann, D., A. Kraay, and M. Mastruzzi. 2003. Governance matters III: Governance indicators for 1996-2002. World Bank Policy Research Working Paper 3106.

Khan, Mushtaq H., and Kwame Sundaram Jomo. 2000. Rents, rent-seeking and economic development: Theory and evidence in Asia. Cambridge: Cambridge University Press.

Khan, Sarah Ahmad. 1994. Nigeria: The political economy of oil. Oxford: Oxford University Press.

Klare, Michael T. 2004. Blood and oil: The dangers and consequences of America's growing dependency on imported petroleum. New York: Metropolitan Books.

Kline, Harvey F. 1995. Colombia democracy under assault. Boulder: Westview Press.

Kohli, Atul. 2004. State-directed development: Political power and industrialization in the global periphery. Cambridge: Cambridge University Press.

Korchagina, Valeria. 2004. Kagalovsky makes new Yukos offer. Moscow Times, December 15.

Lane, Philip R., and Aaron Tornell 1997. Voracity and growth. Discussion Paper 1807. Harvard Institute of Economic Research, Harvard University, Cambridge, MA.

Leite, Carlos, and Jens Weidmann. 1999. Does mother nature corrupt? Natural resources, corruption, and economic growth. IMF Working Paper 99/85. 
Lewis, Stephen R. 1984. Development problems of the mineral-rich countries. In Economic structure and performance, ed. Moshe Syrquin, Lance Taylor, and Larry E. Westphal, 157-77. New York: Academic Press.

Lieuwen, Edwin. 1954. Petroleum in Venezuela: A history. Berkeley: University of California Press.

Lipset, Seymour Martin. 1960. Political man: The social bases of politics. Garden City, NY: Doubleday.

Mauro, Paolo, 1995. Corruption and growth. The Quarterly Journal of Economics 110 (3): 681-712.

McMahon, Gary. 1997. The natural resource curse: Myth or reality? Mimeo, World Bank Institute.

McPherson, Charles P. 2002. Petroleum revenue management in developing countries. Washington, DC: World Bank.

Mikesell, Raymond F. 1997. Explaining the resource curse, with specific reference to mineral exporting countries. Resources Policy 23 (4): 191-99.

Mitra, Pradeep K. 1994. Adjustment in oil-exporting developing countries. Cambridge: Cambridge University Press.

Olson, Mancur. 1982. The rise and decline of nations: Economic growth, stagflation, and social rigidities. New Haven: Yale University Press.

Palley, Thomas I. 2003. Combating the natural resource curse with citizen revenue distribution funds: Oil and the case of Iraq. Foreign Policy in Focus (December): $1-12$.

Philip, George. 1994. The political economy of international oil. Edinburgh: Edinburgh University Press.

Ross, Michael L. 2001a. Does oil hinder democracy? World Politics 53 (3): 325-61.

- 2001b. Extractive sectors and the poor: An Oxfam America report. Boston, MA: Oxfam America.

- 2001c. Timber booms and institutional breakdown in Southeast Asia, Cambridge: Cambridge University Press.

Rutland, Peter. 1997. Lost opportunities: Energy and politics in Russia. NBR Analysis 8 (5).

Sachs, Jeffrey D., and Andrew M. Warner. 1995. Natural resource abundance and economic growth. NBER Working Paper 5398.

Sala-I-Martin, Xavuer, and Arvind Subramanian. 2003. Addressing the natural resource curse: An illustration from Nigeria. IMF Working Paper WP/03/139.

Sarraf, Maria, and Moortaza Jiwanji. 2001. Beating the resource curse: The case of Botswana. Environmental Economics Series, Paper 83, World Bank.

Save the Children, 2003. Lifting the resource curse: Extractive industry, children and governance. London: Save the Children.

Shafer, D. Michael. 1994. Winners and losers: How sectors shape the developmental prospects of states. Ithaca: Cornell University Press.
Shleifer, Andrei and Robert Vishny. 1994. Politicians and firms. Quarterly Journal of Economics 109 (4): 995-1025.

Smith, Benjamin. 2004. Oil wealth and regime survival in the developing world, 1960-1999. American Journal of Political Science 48 (2): 232-46.

Steiner, Richard. 2003. Models of public oversight of government and industry. In Caspian oil windfalls: Who will benefit? ed. Svetlana Tsalik, 71-88. New York: Open Society Institute, Caspian Revenue Watch.

Stevens, Paul. 2003. Resource impact: A curse or a blessing? Centre for Energy, Petroleum and Mineral Law and Policy, University of Dundee, Unpublished Working Paper.

Stiglitz, Joseph. 2004. We can now cure Dutch disease. The Guardian, August 18.

Teichman, Barbara. 1988. Policy-making in Mexico: From boom to crisis. Boston: Allen and Unwin.

Tollison, Robert D. 1982. Rent-seeking: A survey. Kyklos 35: 575-602.

Transparency International. 2004. Global corruption report. London: Pluto Press.

Tsalik, Svetlana, ed. 2003. Caspian oil windfalls: Who will benefit? New York: Open Society Institute, Caspian Revenue Watch.

U.S. Department of Energy, Energy Information Administration (DoE/EIA). 2004. International energy outlook 2004. Washington, DC: DoE/EIA. http://www.eia.doe.gov/oiaf/ieo/index.html.

Usui, Norio. 1997. Dutch disease and policy adjustments to the oil boom: A comparative study of Indonesia and Mexico. Resources Policy 23 (4): 151-62.

Wade, Robert. 1990. Governing the market: Economic theory and the role of government in East Asia industrialization. Princeton: Princeton University Press.

Wantchekon, Leonard. 1999. Why do resource dependent countries have authoritarian governments? Leitner Working Paper 1999-11. New Haven: Yale Center for International and Area Studies.

Weinthal, Erika and Pauline Jones Luong. 2001. Energy wealth and tax reform in Russia and Kazakhstan. Resources Policy 27 (4): 215-23.

- Forthcoming. The paradox of energy sector reform in Russia. In The state after communism: Governance in the new Russia, ed. Timothy Colton and Stephen Holmes.

World Bank. 1993. The East Asian miracle: Economic growth and public policy. Washington, DC: World Bank Group and Oxford University Press.

World Bank. 2001a. World development indicators 2000. Washington, DC: World Bank.

- 2001b. The Chad-Cameroon petroleum development and pipeline project: Notes on the project (June). 
2001c. Trade and foreign exchange policies in Iran: Reform agenda, economic implications and impact on the poor. Washington, DC: World Bank.

- 2002. Worldwide governance research indicators dataset 2002. Washington, DC: World Bank.
2003. Measuring the quality of governance. Development News, July 14.

. 2004. World development indicators 2003. Washington, DC: World Bank. 